\title{
HUBUNGAN KADAR ALANINE AMINOTRANSFERASE (ALT) TINGGI TERHADAP HASIL ANTIBODI VIRUS HEPATITIS A PADA PENDERITA DEMAM
}

\section{RELATIONSHIP BETWEEN HIGH ALANINE AMINOTRANSFERAGE (ALT) LEVELS AND ANTIBODY OF HEPATITIS A VIRUS IN FEVER PATIENTS}

\author{
Rahayu Anggraini1, Ima Nadatein1, Afvidza Delly Virlianna2. \\ 1 Prodi S2 Keperawatan, Fakultas Keperawatan dan Kebidanan, Universitas Nahdlatul Ulama. \\ Surabaya \\ 2 Prodi D4 Analis Kesehatan, Fakultas Kesehatan, Universitas Nahdlatul Ulama. Surabaya
}

\begin{abstract}
Hepatitis $A$ is caused by the Hepatitis A virus (HAV) which is a self limiting disease and provides lifelong immunity. HAV sufferers are characterized by fever, nausea, vomiting, decreased appetite, dark yellow urine, pale stools, and high Alanine Aminotransferase (ALT) results. The purpose of this study was to determine whether there is a relationship between high levels of Alanine Aminotransferase (ALT) and levels of Hepatitis A Virus $(H A V)$ antibodies at the Jemursari Islamic Hospital in Surabaya. This type of research is observational with cross-sectional analytic design. The sampling technique was done by purposive sampling with the inclusion criteria of high ALT levels. The number of research samples as many as 27 respondents who examined IgG HAV and IgM HAV using the Rapid Test IgG and IgM HAV brand V Care. The results of this study showed that there was no significant relationship between high ALT levels and the incidence of Hepatitis A with $p=$ $0.185(p>0.05)$ with the Spearman Correlation test.
\end{abstract}

Keywords: Alanine Aminotransferase (ALT), Antibody of Hepatitis A Virus, Fever Patients.

\begin{abstract}
ABSTRAK
Penyakit Hepatitis A disebabkan oleh virus Hepatitis A (HAV) yang merupakan self limiting desease dan memberikan kekebalan seumur hidup. Penderita HAV ditandai dengan demam, mual, muntah, nafsu makan berkurang, urin berwarna kuning tua, feses berwarna pucat, dan hasil Alanine Aminotransferase (ALT) tinggi. Tujuan penelitian ini untuk mengetahui apakah ada hubungan kadar Alanine Aminotransferase (ALT) tinggi terhadap kadar antibodi Hepatitis A Virus (HAV) di Rumah Sakit Islam Jemursari Surabaya. Jenis penelitian ini adalah observasional dengan rancangan Cross-sectional analitik. Teknik pengambilan sampel dilakukan secara purposive sampling dengan kriteria inklusi kadar ALT tinggi. Jumlah sampel penelitian sebanyak 27 responden yang diperiksa IgG HAV dan IgM HAV menggunakan Rapid Test IgG dan IgM HAV merek V Care.
\end{abstract}


Hasil penelitian ini menunjukan tidak terdapat hubungan yang signifikan antara kadar ALT tinggi terhadap kejadian Hepatitis A dengan $p=0,185(p>0,05)$ melalui uji Korelasi Spearman.

Kata kunci: Alanine Aminotransferase (ALT), Antibodi Hepatitis A Virus, Penderita Demam.

\author{
Alamat Korespondensi $\quad$ : Jl. Raya Jemursari No.57, Jemur Wonosari, Jawa Timur \\ Email : anggrek@unusa,ac.id
}

\title{
PENDAHULUAN
}

Hepatitis A adalah peradangan organ hati yang disebabkan oleh infeksi virus hepatitis A. Infeksi ini akan mengganggu kerja organ hati dan dapat menular dengan mudah, melalui makanan atau minuman yang terkontaminasi virus hepatitis A. Di dunia terjadi sekitar 1,5 juta penderita hepatitis A dengan perkiraan sekitar 10 juta terinfeksi setiap tahunnya. (Wasley, A, 2006) Umumnya terjadi di dunia dengan sanitasi yang buruk dan tidak cukup air bersih. (Matheny, SC,

2012) Di negara berkembang sekitar $90 \%$ anak-anak pada umur sepuluh tahun pernah terinfeksi dan akan kebal pada saat dewasa, kadang-kadang dapat terjadi wabah di negara berkembang, karena anak-anak tidak divaksinasi. Di tahun 2010, Hepatitis A akut menyebabkan 102,000 kematian (Lozano, R, 2012).

Hepatitis A disebabkan oleh infeksi virus Hepatitis A (HAV) yang merupakan self limiting desease dan memberikan kekebalan seumur hidup. HAV adalah virus RNA27-nm non-envelop, termasuk genus Hepatovirus, famili Picornavirus yang bersifat termostabil, tahan asam, tahan terhadap cairan empedu, dan stabil pada suhu $-20^{\circ} \mathrm{C}$ serta $\mathrm{pH}$ yang rendah $(\mathrm{pH} 3,0)$, sehingga efisien dalam transmisi fekal-oral. Kerusakan hepar yang terjadi disebabkan karena mekanisme imun yang diperantarai sel $\mathrm{T}$. Infeksi HAV tidak dapat menyebabkan terjadinya hepatitis kronis atau persisten. Infeksi HAV menginduksi proteksi jangka panjang terhadap re-infeksi (Arief, 2011).

Tanda dan gejala hepatitis A adalah kelelahan, demam, mual dan muntah, kehilangan nafsu makan, dan menguningnya kulit dan bagian putih mata (jaundice). Menguning atau icteric dikarenakan meningkatnya kadar bilirubin, diikuti urine berwarna gelap seperti teh, disertai diare dengan kotoran berwarna terang atau mirip tanah liat. Hepatitis A dibagi menjadi 3 stadium yaitu pendahuluan (prodromal) dengan gejala letih, lesu, demam, kehilangan nafsu makan dan mual. Stadium kedua dengan gejala kuning (stadium ikterik), sedangkan stadium ketiga adalah kesembuhan (konvalesensi). Gejala kuning tidak selalu ditemukan. Untuk memastikan diagnosis dilakukan pemeriksaan enzim hati, Serum Glutamic Oxaloacetic Transaminase (SGOT) atau aspartate aminotransferase (AST) dan Serum Glutamic Pyruvate Transaminase (SGPT) atau alanin aminotransferase (ALT). Karena pada hepatitis A juga bisa terjadi radang saluran empedu, maka pemeriksaan gama-GT dan alkali fosfatase juga dilakukan di samping kadar bilirubin (Ciocca M., 2000). 
Tes virus hepatitis A adalah tes darah yang dilakukan untuk mencari protein (antibodi) yang diproduksi oleh tubuh sebagai reaksi dari virus hepatitis A. Jenis protein ini hanya akan terdeteksi dalam tubuh jika saat ini sedang terjangkit virus hepatitis A atau pernah memiliki riwayat medis serupa sebelumnya. Sangat penting untuk dapat mengidentifikasi tipe virus hepatitis A yang menyebabkan infeksi, agar dapat dilakukan langkah pencegahan, penyebaran penyakit dan untuk memulai terapi yang optimal. Infeksi HAV menyebar melalui makanan atau air yang telah terkontaminasi oleh feses dari orang pengidap HAV. Antibodi IgM anti-HAV menunjukan bahwa infeksi hepatitis A baru terjadi. Antibodi IgM anti-HAV umumnya dapat terdeteksi dalam darah kurang lebih 2 minggu setelah kontak pertama dengan HAV. Antibodi jenis ini akan menghilang setelah $3-12$ bulan setelah infeksi. Antibodi IgG anti-HAV menunjukan bahwa pernah terjangkit infeksi virus hepatitis A. Antibodi IgG anti-HAV akan muncul $8-12$ bulan setelah kontak pertama infeksi dan akan terus menetap selamanya dalam darah sebagai perlindungan (imunitas) dari infeksi HAV (Safitri, 2019). Dari uraian di atas, akan dilakukan penelitian yang menghubungkan kadar ALT terhadap antibodi Hepatitis A virus, di mana nilai normal ALT adalah

0-35 u/L (mikro perliter) (Muhlisin, 2019).

Rumusan masalah apakah ada hubungan kadar Alanine Aminotransferase (ALT) tinggi terhadap hasil Antibodi Virus Hepatitis A pada Penderita Demam? Tujuan Penelitian ini untuk mengetahui hubungan kadar Alanine Aminotransferase (ALT) tinggi terhadap hasil antibodi Virus Hepatitis A pada penderita demam.

\section{Pengertian Virus Hepatitis A}

Hepatitis A, istilah ini pertama kali diperkenalkan pada tahun 1967 sebagai infeksi hati yang disebabkan oleh virus hepatitis A (HAV). Virus Hepatitis A (HAV) situs replikasi utamanya ada di dalam sel hepatosit (Krugman et al., 1967). HAV adalah virus RNA beruntai tunggal positif yang merupakan milik keluarga Picornavaridae dan merupakan anggota dari genus Hepatovirus. Berbeda dengan anggota keluarga lainnya, HAV membutuhkan periode adaptasi yang panjang untuk tumbuh dalam kultur sel, sifat replikasinya secara perlahan dan jarang menghasilkan efek sitopatik (Cromeans et al., 1987; Lemon, 1992). Morfologi dan ukuran Virion tidak ada, icosahedral simetri nukleokapsid, berbentuk bulat, berdiameter 27-32 nm, mengandung asam nukleat RNA linier, beruntai tunggal, panjangnya $\sim 7,5 \mathrm{~kb}$. Sifat fisiko-kimia, HAV mempertahankan infektivitasnya dalam pH 1.0 selama 2 jam pada suhu kamar dan masih bersifat menular selama 5 jam. HAV sangat tahan terhadap deterjen dan pelarut organik seperti eter dan kloroform. Autoclave pada $121^{\circ} \mathrm{C}$ sangat efektif. HAV tidak aktif pada 98-100 ${ }^{\circ}$ $\mathrm{C}$ dalam beberapa menit. Virus ini bertahan selama berhari-hari sampai berbulanbulan dalam air tawar, air laut, air limbah, tanah, sedimen laut, tiram hidup yang terkontaminasi secara eksperimental, dan kue isi krim. Tiram terinokulasi karena terkontaminasi tinja, dan bila hanya dipanaskan pada suhu $60^{\circ} \mathrm{C}$ selama 19 menit, kemudian disegel dalam kaleng, maka masih dapat mentransmisikan HAV. HAV dapat diinaktivasi dengan radiasi UV, formalin, $\beta$-propiolactone, yodium, dan senyawa yang mengandung klor atau sodium hipoklorit. Infektivitas HAV secara substansial berkurang $70 \%$ dalam etanol pada suhu $25^{\circ} \mathrm{C}$. 

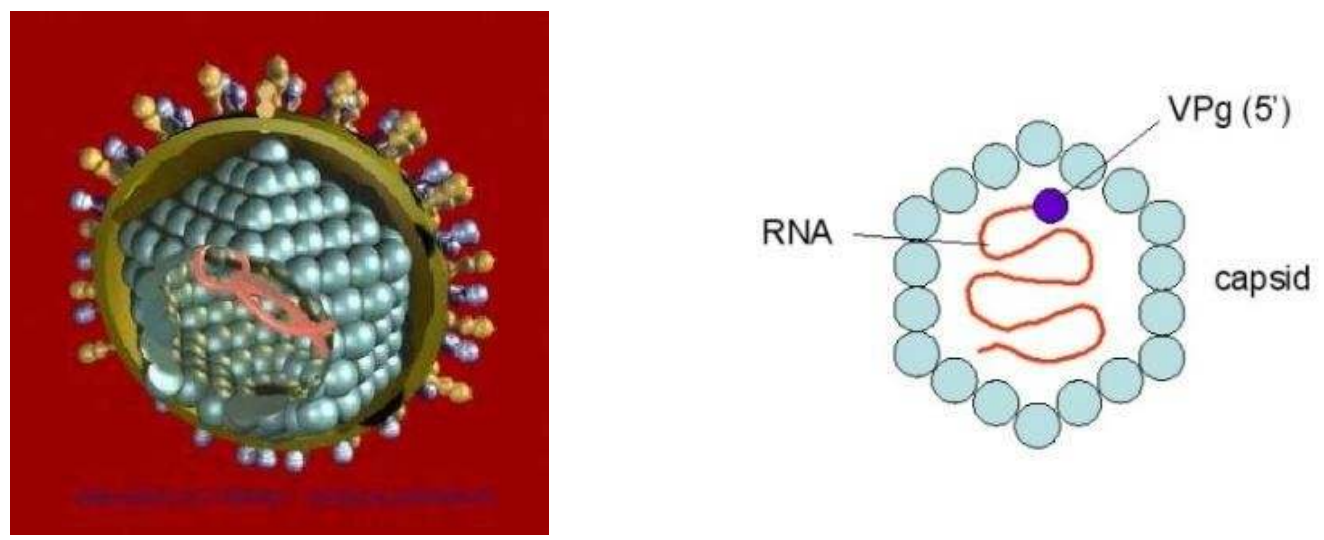

Gambar 1 Virus Hepatitis A (IPD UI, 2009)

\section{Penyakit Hepatitis A}

Penyakit Hepatitis A disebut juga sebagai peradangan hati akibat infeksi Hepatitis A Virus (HAV). Penularan terjadi melalui rute faecal-oral melalui makanan dan minuman yang terkontaminasi oleh HAV (Sievert, et al., 2010). Hepatitis A merupakan penyakit yang seringkali menimbulkan wabah di dunia. KLB hepatitis A tidak hanya terjadi pada negara miskin dan berkembang. Menurut WHO (2013) sebanyak 1,4 juta pasien di dunia mengalami penyakit Hepatitis A setiap tahunnya.

Infeksi HAV memberikan kekebalan seumur hidup dan dapat menghasilkan efek dari asimptomatik sampai dengan kegagalan hati fulminan yang dalam beberapa kasus dapat menyebabkan kematian (Ross dan Anderson, 1991). Namun, tingkat kematian dalam infeksi HAV lebih rendah $0,1 \%$, namun risiko lebih tinggi bila terjadi pada anak-anak dan manula karena dapat menimbulkan penyakit hati akut (Akriviadis dan Redeker, 1989).

Di negara berkembang sebagian besar Hepatitis A terjadi pada anak-anak. Di negara maju, sebanyak $20 \%$ terjadi pada orang dewasa muda. Insiden dan keparahan penyakit meningkat lebih besar seiring meningkatnya usia. Berbagai wabah besar yang pernah terjadi banyak disebabkan oleh air, susu, atau makanan yang terkontaminasi. Kerang dapat terinfeksi dari air laut dan menjadi media penularan (Mandal, et al., 2004). Imunitas jangka panjang timbul setelah terkena serangan HAV. Masa inkubasi berkisar antara 14-42 hari, rata-rata terjadi selama 28 hari. Antibodi Hepatitis A bisa dideteksi dalam darah ketika infeksi telah menampilkan gejala, sekitar 15-45 hari setelah pajanan HAV. IgM anti-HAV adalah antibodi pertama terdeteksi di dalam darah, sebagai tanda peradangan akut dan setelah 3-6 bulan setelah infeksi HAV, IgM anti-HAV tidak terdeteksi lagi dalam darah, sebagai penggantinya IgG anti-HAV yang terdeteksi dan bisa bertahan selama bertahun-tahun. (Mandal, et al., 2004).

Distribusi Hepatitis A tersebar di seluruh dunia, dan dapat muncul secara sporadis sebagai wabah. Kecenderungan waktu munculnya wabah Hepatitis A adalah secara siklis. Di negara berkembang biasanya orang dewasa sudah memiliki kekebalan terhadap HAV, namun pada penduduk dewasa muda lebih rentan terkena 
wabah Hepatitis A. Hal tersebut mengakibatkan frekuensi KLB cenderung meningkat (Chin, 2009).

\section{Patogenesis Virus Hepatitis A}

Di awali dengan masuk nya virus Hepatitis A ke dalam saluran pencernaan, kemudian masuk ke dalam aliran darah menuju hati (vena porta), lalu menginvasi sel parenkim hati. Di sel parenkim hati, virus mengalami replikasi yang menyebabkan sel parenkim hati menjadi rusak. Setelah itu virus akan keluar dan menginvasi sel parenkim yang lain atau masuk ke dalam ductus biliaris yang akan dieksresikan bersama feses. Sel parenkim yang telah rusak akan merangsang reaksi inflamasi yang ditandai dengan adanya agregasi makrofag, pembesaran sel kupfer yang akan menekan ductus biliaris, sehingga aliran bilirubin direk terhambat, kemudian terjadi penurunan ekskresi bilirubin ke usus. Keadaan ini menimbulkan ketidakseimbangan antara uptake dan ekskresi bilirubin dari sel hati sehingga bilirubin yang telah mengalami proses konjugasi (direk) akan terus menumpuk dalam sel hati yang akan menyebabkan reflux (aliran kembali ke atas) ke pembuluh darah, sehingga akan bermanifestasi kuning pada jaringan kulit terutama pada sklera mata kadang disertai rasa gatal dan urine seperti teh pekat akibat partikel bilirubin direk berukuran kecil masuk ke ginjal dan di eksresikan melalui urin. Akibat bilirubin direk yang kurang dalam usus mengakibatkan gangguan dalam produksi asam empedu (produksi sedikit), sehingga proses pencernaan lemak terganggu (lemak bertahan dalam lambung dengan waktu yang cukup lama) yang menyebabkan renggangan pada lambung, sehingga merangsang saraf simpatis dan saraf parasimpatis mengakibatkan teraktifasinya pusat muntah yang berada di medula oblongata sehingga timbulnya gejala mual, muntah dan menurunnya nafsu makan. (Kumar,2007).

Pengamatan pada fase darah (viremia) diamati bersamaan pada feses dan sering mendahului selama perkembangan gejala selama 2 minggu. Konsentrasi virus yang ditemukan dalam darah biasanya relatif rendah ( $\sim 103-5$ virions $/ \mathrm{mL}$ ). HAV dapat bersirkulasi dalam darah tertutup lipid terkait fragmen membran yang secara sementara dapat melindungi virus dari antibodi sistem imun host. Viremia mungkin ada selama tahap awal penyakit, tetapi biasanya segera berakhir setelah hepatitis berkembang. Asam nukleat spesifik virus HAV dapat dideteksi dalam darah selama 30 hari atau lebih sejak awal gejala (CDC, 2013).

Immunopatogenesis dari Hepatitis A dengan dimulainya onset dari gejala klinis, antibodi IgM dan IgG anti-HAV dapat terdeteksi.35 Pada hepatitis A akut, kehadiran IgM anti-HAV terdeteksi setelah 3 minggu setelah paparan, kadar IgM dan IgA anti-HAV akan terus meningkat selama 4-

6 minggu, lalu terus menurun sampai level yang tidak terdeteksi dalam waktu 6 bulan infeksi, di mana kemudian disusul kadar IgG anti-HAV yang baru dapat dideteksi setelah 2 bulan dan mencapai puncaknya 4 bulan setelah timbulnya gejala. Antibodi IgG anti-HAV akan bertahan selama bertahun-tahun setelah infeksi dan dapat memberikan imunitas seumur hidup. Pada masa penyembuhan, regenerasi sel hepatosit segera terjadi. Jaringan hepatosit yang rusak biasanya pulih dalam 8-12 minggu (Sanityoso, A., 2009). 


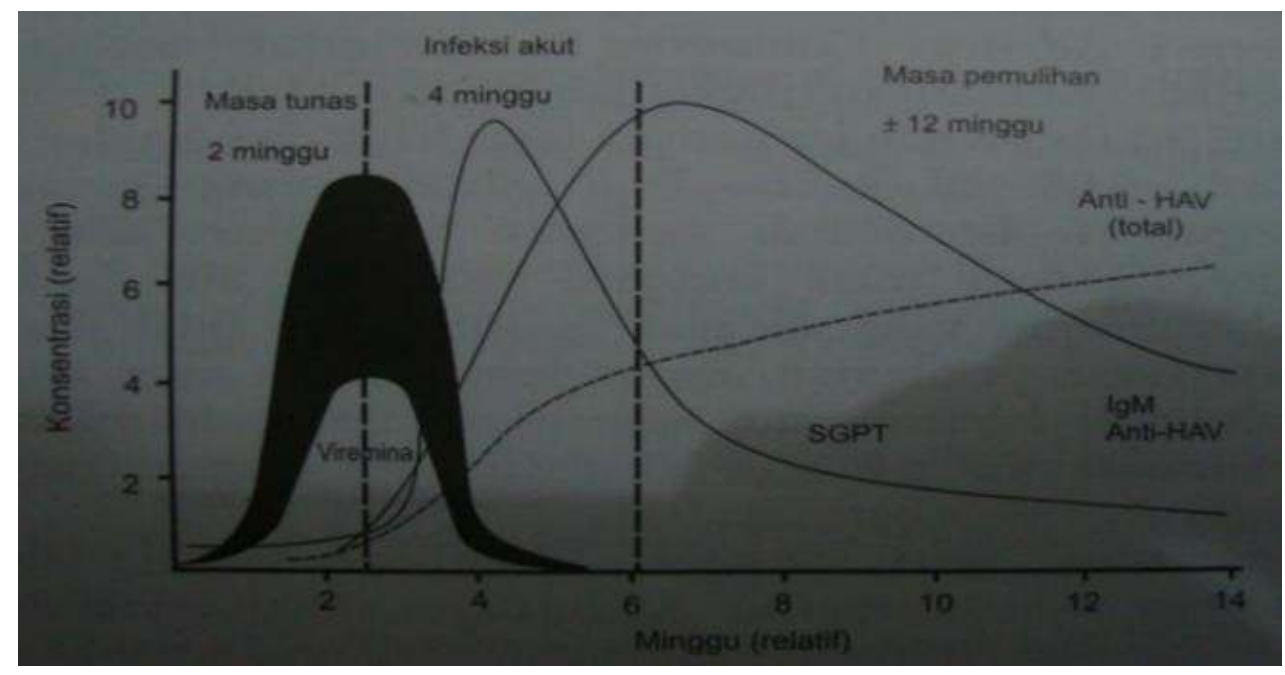

Gambar 2 Gambaran fase tunas, fase infeksi akut, dan fase pemulihan pada penderita Hepatitis A. (Sanityoso, A., 2009). Pemeriksaan Alanine

\section{Aminotransferase (ALT)}

Alanine Aminotransferase (ALT), sebelumnya disebut Glutamic Pyruvic Transaminase (GPT) dan Aspartate Aminotransferase (AST), sebelumnya disebut Glutamic Oxalacetic Transaminase (GOT) adalah yang paling penting dari sekelompok enzim, aminotransferases atau transaminase, mengkatalisis konversi asam $\alpha$-keto menjadi asam amino dengan transfer gugus amino. Sebagai enzim spesifik hati, ALT hanya meningkat secara signifikan pada penyakit hepatobilier, sedangkan peningkatan kadar AST, dapat terjadi sehubungan dengan kerusakan jantung atau otot rangka serta parenkim hati. Pengukuran parallel ALT dan AST diterapkan untuk membedakan kerusakan hati atau jantung atau otot rangka. Rasio AST / ALT digunakan untuk diagnosis banding pada penyakit hati, sedangkan rasio $<1$ menunjukkan kerusakan hati ringan, rasio $>1$ berhubungan dengan penyakit hati parah dan seringkali kronis.

Metode penentuan kadar ALT adalah IFCC (International Federation of Clinical), dan prinsip reaksinya adalah:

$$
\begin{gathered}
\text { L-Alanine }+2 \text {-Oxoglutarate }<\text { ALT }>\text { L-Glutamate }+ \text { Pyruvate } \\
\text { Pyruvate }+\mathrm{NADH}+\mathrm{H}+<\mathrm{LDH}>\text { D-Lactate }+ \text { NAD }+
\end{gathered}
$$

Penambahan pyridoxal-5-phosphate (P-5-P), direkomendasikan oleh IFCC, menjadi stabil oleh aktivitas transaminase dan guna menghindari nilai yang sangat rendah dalam sampel yang mengandung P-5-P endogen yang tidak mencukupi, misalnya pada pasien miokard infark, penyakit hati dan pasien perawatan intensif. (Thomas L. 1998; Bergmeyer HU, 1986)

Nilai normal SGPT (ALT) pada wanita $<34 \mathrm{U} / \mathrm{L}$ dan pada Pria $<45 \mathrm{U} / \mathrm{L}$ (Schumann G, 2002). Prosedur kerja: sampel atau kalibrator $100 \mu \mathrm{L}$ ditambahkan pereaksi Mono $1000 \mu \mathrm{L}$, kemudian dicampur, setelah 1 menit langsung dibaca 
absorbansi dan stopwatch mulai dipasang. pada menit ke 1, 2 dan 3 pada panjang gelombang $340 \mathrm{~nm}$. Kadar ALT dapat ditentukan menggunakan Faktor 1745 (pada panjang gelombang $340 \mathrm{~nm}$ ), atau bila menggunakan kalibrator, digunakan Rumus:

$\operatorname{ALT}(\mathrm{U} / \mathrm{L})=\Delta \mathrm{A} / \min ($ sample $) / \Delta \mathrm{A} / \min$ (Calibrator) X Conc. Calibrator $(\mathrm{U} / \mathrm{L})$

\section{Pemeriksaan IgM anti-HAV dan IgG anti-HAV dengan metode Rapid Test}

One Step HAV IgG/IgM test adalah tes kualitatif menggunakan membrane strip berbasis immunoassay untuk mendeteksi antibodi ( $\operatorname{IgG} / \operatorname{IgM})$ virus Hepatitis A dalam serum/plasma. Alat uji terdiri dari : Pad konjugat berwarna merah anggur yang mengandung antigen rekombinan HAV terkonjugasi dengan emas koloid (konjugat HAV) dan konjugat IgG Colloidal Gold. Strip membrane nitroselulosa mengandung dua pita uji (T1 dan pita T2) di mana pada pita test telah dilapisi antibodi HAV untuk mendeteksi IgG anti-HAV dan IgM anti-HAV. Pada pita C (pita control) telah dilapisi dengan IgG goat anti rabbit. Ketika volume spesimen uji telah diteteskan dan volume telah memadai ke dalam sumur sampel dari kaset uji, maka spesimen akan bermigrasi dengan aksi kapiler melintas kaset. IgG anti-HAV atau IgM anti-HAV. Jika antibody HAV ada dalam spesimen, maka akan mengikat konjugat HAV membentuk komplek imun. Komplek imun kemudian ditangkap oleh antibody anti IgM yang telah dilapisi pada pita T1, menghasilkan warna merah anggur menunjukan hasil positif IgM anti-HAV. Begitu pula bila di dalam sampel mengandung antibodi-HAV akan berikatan dengan konjugat HAV akan membentuk komplek imun. Komplek imun kemudian akan bereaksi dengan antibody anti IgG yang telah dilapisi pada pita $\mathrm{T} 2$, menghasilkan warna merah anggur menunjukan hasil positif IgG anti-HAV. Tidak adanya warna pada pita $\mathrm{T}$ (T1 dan T2) menunjukan hasil IgG anti-HAV dan IgM anti-HAV negative. Test ini berisi control internal (pita $\mathrm{C}$ ) yang akan selalu menunjukan pita berwarna merah muda dari komplek imun goat anti rabbit IgG/rabbit IgG-gold terlepas dari pengembangan warnanya pada salah satu pita T. Jika warna pada pita $\mathrm{C}$ tidak terbentuk, maka hasil tes dinyatakan tidak valid dan spesimen harus di uji ulang dengan perangkat lain. (Insert Kit"V care", 2003)

Prosedur pemeriksaan: sebelum melakukan uji, dipastikan alat dan bahan sudah siap dan berada pada suhu kamar, reagen dan spesimen harus dikondisikan pada suhu ruang, strip IgM/IgG anti-HAV dikeluarkan dari wadah dan diletakkan pada tempat kering dan datar, kemudian ditambahkan 8 tetes buffer serum ke tabung specimen dilanjutkan dengan penetesan $2 \mu$ spesimen ke dalam tabung specimen, kemudian dihomogenkan hingga tercampur rata dengan membolakbalikkan tabung, kemudian dipipet 3 tetes (sekitar $100 \mu$ l) dimasukkan ke dalam sumur (S). Selanjutnya ditunggu sampai pita $\mathrm{C}$ muncul warna dalam waktu 15 menit. Setelah waktu tersebut hasil dinyatakan tidak valid. (Insert Kit "V care", 2003). 




Gambar 3 Prosedur kerja IgG anti-HAV dan IgM anti HAV Rapid Test (Insert Kit "Juschek", 2018)

Interpretasi hasil, dinyatakan negatif, bila hanya pita $\mathrm{C}$ terlihat berwarna di perangkat uji. Dinyatakan IgM anti-HAV positif, bila pada pita $\mathrm{C}$ dan pita $\mathrm{T} 1$ terlihat warna dan dinyatakan IgG anti-HAV positif, bila pada pita $\mathrm{C}$ dan pita $\mathrm{T} 2$ terlihat warna. Dinyatakan positif untuk keduanya IgM anti-HAV positif dan IgG anti-HAV positif, bila terlihat pita C, pita T1 dan pita T2 terlihat warna. Dinyatakan Invalid, bila pita $\mathrm{C}$ tidak muncul warna. Volume sampel yang tidak cukup atau teknik prosedur yang salah adalah penyebab terbesar dari gagalnya pita $\mathrm{C}$ tidak muncul warna pada alat uji. Hal ini berarti tes harus diulang dengan perangkat uji yang baru. (Insert Kit "Juschek", 2018)

\section{METODE PENELITIAN}

Jenis penelitian ini adalah observasional dengan rancangan Cross-sectional analitik. Populasi penelitian adalah penderita Rumah Sakit Islam Jemursari Surabaya. Sampel penelitian diambil secara purposive sampling dari populasi di Rumah Sakit Islam Jemursari Surabaya dan memenuhi kriteria inklusi.

\section{HASIL DAN DISKUSI}

Karakteristik responden berdasarkan jenis kelamin dan kelompok usia pada penderita demam disajikan dalam gambar 5.1. 


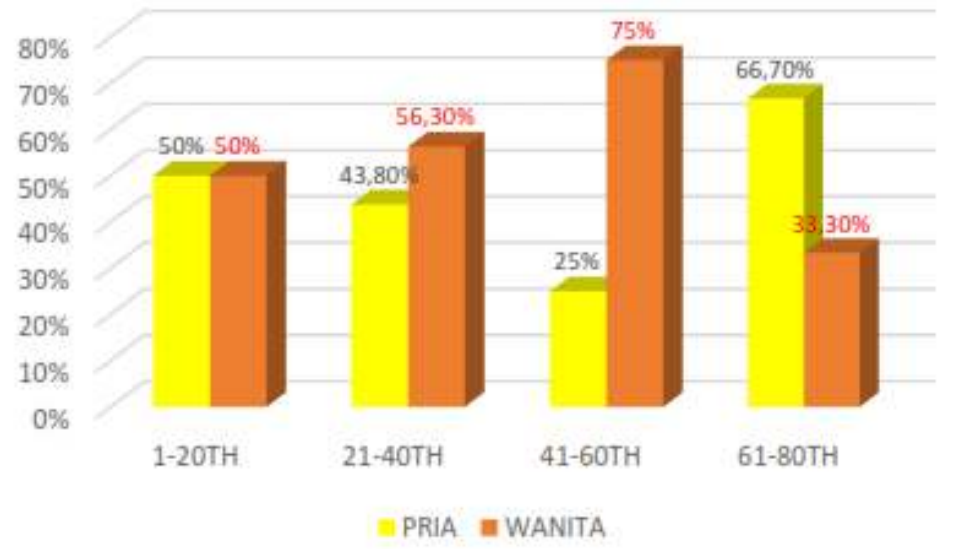

Gambar 4 Diagram Venn antara Jenis Kelamin dan Umur

Pada gambar 5.1 dapat terlihat bahwa kriteria responden berdasarkan jenis kelamin dan umur, bahwa pada umur antara 41-60 tahun didapatkan wanita terbanyak sebanyak $75 \%$, sedangkan pria paling sedikit sebanyak $25 \%$. Hal ini dimungkinkan wanita pada usia 41-60 tahun lebih suka makan-makanan di luar daripada masak sendiri. Namun pria pada usia 61-80 tahun sebanyak 66,7\%, menderita demam tertinggi, kemungkinan pria lebih menyukai makan-makanan di luar daripada masak sendiri.

\section{Karakteristik kadar ALT dibanding antibodi HAV}

Hasil pemeriksaan ALT dibanding hasil IgG anti-HAV dan IgM anti-HAV didapatkan distribusi hasil seperti pada gambar 5.2

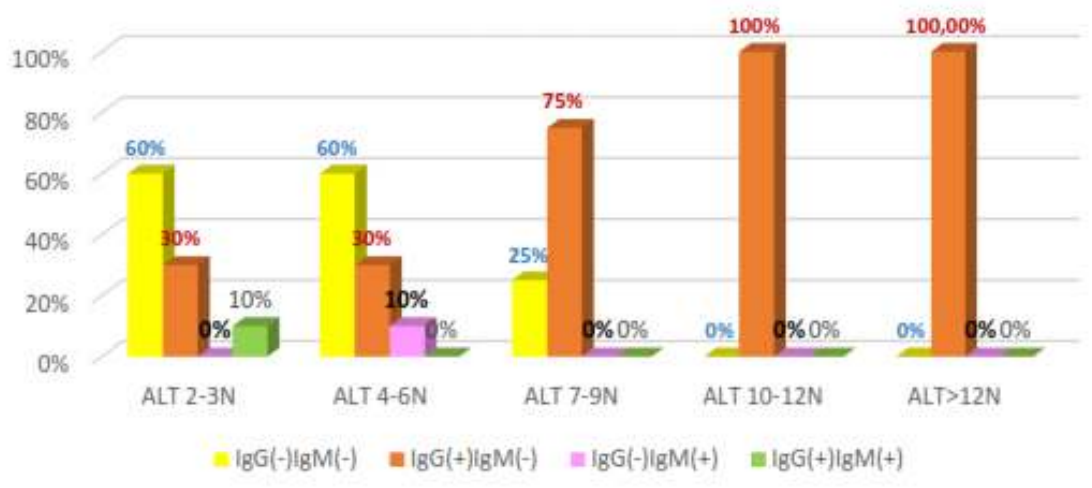

Gambar 5.2 Diagram Venn antara ALT dan anti-HAV

Pada gambar 5.2 dapat terlihat bahwa pada hasil ALT tinggi dari semua kelompok didapatkan hasil IgG anti-HAV (+) dan IgM anti-HAV (-) yang menandakan bahwa semua responden pernah menderita HAV tetapi sudah sembuh. Sedangkan hasil ALT tinggi dengan hasil IgG anti-HAV (-) dan IgM anti-HAV () yang menandakan bahwa penderita demam sama sekali belum terinfeksi HAV 
dan hanya terdapat pada kadar ALT 2-3 X Normal, 4-6 X Normal dan 7-9 X Normal.

\section{Hasil Uji Statistik}

\section{Uji Normalitas}

Uji normalitas digunakan untuk mengetahui suatu sampel yang digunakan berdistribusi normal atau tidak. Uji normalitas pada penelitian ini diketahui menggunakan SPSS for window 23 dengan uji Shapiro - Wilk didapatkan nilai $\mathrm{p}=0,000$ pada ALT dan anti HAV yang artinya data kedua uji didapatkan tidak berdistribusi normal karena nilai $\mathrm{p}<0,05$.

Tests of Normality

Tabel 1 Hasil Uji Normalitas

\begin{tabular}{l|l|l|l|l|l|l}
\hline & \multicolumn{3}{|l|}{ Kolmogorov-Smirnova } & \multicolumn{3}{l}{ Shapiro-Wilk } \\
\cline { 2 - 8 } & Statistic & df & Sig. & Statistic & df & Sig. \\
\hline ALT & 266 & 27 & .000 & .808 & 27 & .000 \\
\hline AB_HA & 284 & 27 & .000 & .736 & 27 & .000
\end{tabular}

a. Lilliefors Significance Correction

\section{Uji Nonparametric Correlations}

Uji Korolasi digunakan untuk mengetahui hubungan antara kadar ALT dengan Anti HAV dihitung menggunakan uji Spearman Correlations, didapatkan nilai $\mathrm{p}=0,185$ yang artinya hubungan antara kedua uji tidak ada hubungan dikarenakan nilai $\mathrm{p}>0,05$.

Tabel 2 Hasil Uji Kolerasi Spearman

Correlations

\begin{tabular}{|c|c|c|c|c|}
\hline \multirow{4}{*}{$\begin{array}{l}\text { Spearman's } \\
\text { rho }\end{array}$} & & & ALT & AB_HAV \\
\hline & \multirow[t]{3}{*}{ ALT } & Correlation Coefficient & 1.000 & .263 \\
\hline & & Sig. (2-tailed) & & .185 \\
\hline & & $\mathrm{N}$ & 27 & 27 \\
\hline & \multirow[t]{3}{*}{ AB_HAV } & Correlation Coefficient & .263 & 1.000 \\
\hline & & Sig. (2-tailed) & .185 & \\
\hline & & $\mathrm{N}$ & 27 & 27 \\
\hline
\end{tabular}

\section{SIMPULAN DAN SARAN}

Bila dilihat karakteristik responden yang menderita demam pada kelompok umur 41- 60 tahun terbanyak pada wanita, sedangkan pada kelompok umur 61-80 tahun terbanyak pada pria. Berdasarkan hasil penelitian dalam mencari hubungan kadar Alanin Aminotransferase (ALT) tinggi terhadap hasil Anti Hepatitis A Virus (HAV), maka dapat disimpulkan bahwa dari sejumlah responden demam didapatkan kesemua kelompok ALT tinggi didapatkan hasil IgG anti-HAV (+) dan 
IgM anti-HAV (-). Hal ini dapat disimpulkan bahwa penderita deman dengan kadar ALT tinggi pernah terinfeksi Hepatitis A, namun saat diteliti mereka telah sembuh.

Penelitian ini perlu dilanjutkan dengan pemeriksaan antibody HAV menggunakan metode ELISA, karena ELISA memiliki sensitivitas dan spesifisitas yang tinggi. Selain itu perlu dihubungkan kadar bilirubin yang tinggi terhadap hasil anti HAV, apakah kadar bilirubin tinggi memang disebabkan oleh infeksi HAV.

\section{DAFTAR PUSTAKA}

1. Arief, S., Sri, Y.S, Hanifah, O. 2011. Buku Ajar GastroenterologiHepatologi. Jakarta : Badan penerbit IDAI.

2. Bergmeyer HU, Horder M, Rej R., 1986. Approved Recommendation (1985) on IFCC Methods for the Measurement of Catalytic Concentration of Enzymes. L.Clin. Chem. Clin. Biochem; 24: 481-495.

3. Centers for Disease Control and Prevention. Hepatitis A FAQs for health professionals. Available at: http://www.cdc.gov/hepatitis/hav/havfaq.htm. Accessed July 1, 2013.

4. Ciocca M., 2000. "Clinical course and consequences of hepatitis A infection". Vaccine. 18: 71-4. doi:10.1016/S0264-410X(99)00470-3. PMID 10683554.

5. CDC, 2009. "Hepatitis A Information for the Public". Center for Disease Control. 2009-09- 17. Diakses tanggal 2011-01-08.

6. JusChek. HAV IgG/IgM Combo Rapid Test Cassette (serum/plasma) Package Insert.

7. Lozano, R (Dec 15, 2012). "Global and regional mortality from 235 causes of death for 20 age groups in 1990 and 2010: a systematic analysis for the Global Burden of Disease Study 2010". Lancet. 380 (9859): 2095-128. doi:10.1016/S0140-6736(12)61728-0. PMID 23245604.

8. Muhlisin A, 2019. SGOT dan SGPT: Nilai normal, Tinggi, Rendah \& Maknanya. Layanan Kesehatan. https://www.honestdocs.id/sgot-sgpt

9. Safitri T., 2019, Tes Hepatitis A. Hello Sehat. https://hellosehat.com/pusatkesehatan/hepatitis/tes-hepatitis-a/

10. Sanityoso, A., 2009. Hepatitis Virus Akut. Buku Ajar Ilmu Penyakit Dalam Jilid I Edisi V. Jakarta. Departemen Ilmu Penyakit Dalam Fakultas Kedokteran Universitas Indonesia.

11. Schumann G, Bonora R, Ceriotti F, Férard G et al., 2002. IFCC primary reference procedure for the measurement of catalytic activity concentrations of enzymes at $37{ }^{\circ} \mathrm{C}$. Part 4 : Reference procedure for the measurement of catalytic concentration of alanine aminotransferase. Clin Chem Lab Med;40: 718-24.

12. Thomas L. 1998. Alanine aminotransferase (ALT), Aspartate aminotransferase (AST). In: Thomas L, editor. Clinical Laboratory Diagnostics. 1st ed. Frankfurt: TH-Books Verlagsgesellschaft; p. 55-65

13. Wasley, A; Fiore, A; Bell, BP (2006). "Hepatitis A in the era of vaccination". Epidemiol Rev. 28: 101-11. doi:10.1093/epirev/mxj012. PMID 16775039. 
14. WHO, 2013. Hepatitis A Fact sheet $N^{\circ} 328 "$. World Health Organization. July 2013. Diakses tanggal 20 February 2014. 